Review

\title{
Hydrogen Sulfide, Oxidative Stress and Periodontal Diseases: A Concise Review
}

\author{
Maria Greabu, Alexandra Totan *, Daniela Miricescu, Radu Radulescu, Justina Virlan and \\ Bogdan Calenic
}

Received: 2 December 2015; Accepted: 30 December 2015; Published: 14 January 2016

Academic Editor: Maurizio Battino

Dental Medicine Faculty, Biochemistry Department, University of Medicine and Pharmacy CAROL DAVILA, 8 Blvd EroilorSanitari, sect.5, 050474 Bucharest, Romania; mariagreabu@yahoo.com (M.G.);

miricescudaniela@yahoo.com (D.M.); radu_radulescu24@yahoo.com (R.R.); roxxanajustina@yahoo.com (J.V.);

bcalenic@yahoo.co.uk (B.C.)

* Correspondence: alexandratotan@yahoo.com; Tel.: +407-2239-6324

\begin{abstract}
In the past years, biomedical research has recognized hydrogen sulfide $\left(\mathrm{H}_{2} \mathrm{~S}\right)$ not only as an environmental pollutant but also, along with nitric oxide and carbon monoxide, as an important biological gastransmitter with paramount roles in health and disease. Current research focuses on several aspects of $\mathrm{H}_{2} \mathrm{~S}$ biology such as the biochemical pathways that generate the compound and its functions in human pathology or drug synthesis that block or stimulate its biosynthesis. The present work addresses the knowledge we have to date on $\mathrm{H}_{2} \mathrm{~S}$ production and its biological roles in the general human environment with a special focus on the oral cavity and its involvement in the initiation and development of periodontal diseases.
\end{abstract}

Keywords: hydrogen sulfide; saliva; periodontitis

\section{Introduction}

Hydrogen sulfide $\left(\mathrm{H}_{2} \mathrm{~S}\right)$, traditionally recognized as a toxic gas with a rotten-egg smell [1], is also a bacterial waste product eliminated in the subgingival pocket $[2,3]$. Periodontal disease has been described as an immune-inflammatory condition characterized by connective tissue breakdown, loss of attachment and alveolar bone resorption [4]. In periodontitis pathogenesis, inflammatory and immune reactions play the main roles [5], but more and more authors consider also the link between oxidative stress and periodontal problems. Due to $\mathrm{H}_{2} \mathrm{~S}^{\prime}$ s abilities in reducing oxidative stress [6-8] or regulating inflammation [8,9], researchers have started studying $\mathrm{H}_{2} \mathrm{~S}^{\prime}$ s roles in the initiation and progression of periodontal diseases. However, results are controversial.

Interestingly, $\mathrm{H}_{2} \mathrm{~S}$ can be regarded as a double-faced molecule: on one side, at lower concentration have antioxidant and cytoprotective activities, but at higher concentrations is cytotoxic and stimulates oxidative stress (OS).

This paper reviews the most significant studies concerning $\mathrm{H}_{2} \mathrm{~S}$ production, its biological roles and implications in periodontitis development.

\section{2. $\mathrm{H}_{2} \mathrm{~S}$-Production}

In mammalian organisms, including the human body, endogenous $\mathrm{H}_{2} \mathrm{~S}$ synthesis is generally connected to three enzymes: 3-mercaptopyruvate sulfurtransferase (3MST), cystathionine $\beta$-synthase (CBS) and cystathionine $\gamma$-lyase (CSE), all three taking part in the cysteine synthesis pathway [10-12] (Figure 1).

It is important to note that the three enzymes are responsible for $\mathrm{H}_{2} \mathrm{~S}$ homeostasis and regulate $\mathrm{H}_{2} \mathrm{~S}$ levels found in the bloodstream. Each of the enumerated enzymes is found at specific sites in 
the organism. Thus, 3MST has a mitochondrial location and is usually present in the brain and blood vessels. The enzyme participates in a series of chemical reactions that starts with cysteine metabolism transformed to 3-mercaptopyruvate by cysteine aminotransferase. Further 3-mercaptopyruvate is reacted to pyruvate and, finally, to $\mathrm{H}_{2} \mathrm{~S}$ by 3MST. CBS is encountered mostly in hepatic, cerebral and nervous tissues. CBS produces $\mathrm{H}_{2} \mathrm{~S}$ as a result of a reaction involving cystathionine generation from cysteine and serine. Similarly, CSE, which resides in blood vessels and hepatic cells, produces $\mathrm{H}_{2} \mathrm{~S}$ starting from cysteine and generates pyruvate and ammonia. $\mathrm{H}_{2} \mathrm{~S}$ catabolism involves several oxidative steps that convert the gas to persulfide, thiosulfate and sulphate, in an organ specific process. Further, $\mathrm{H}_{2} \mathrm{~S}$ oxidation was shown to occur in virtually all cell types and tissues of the human body including colon, kidney, liver, and brain or lung cells [13].

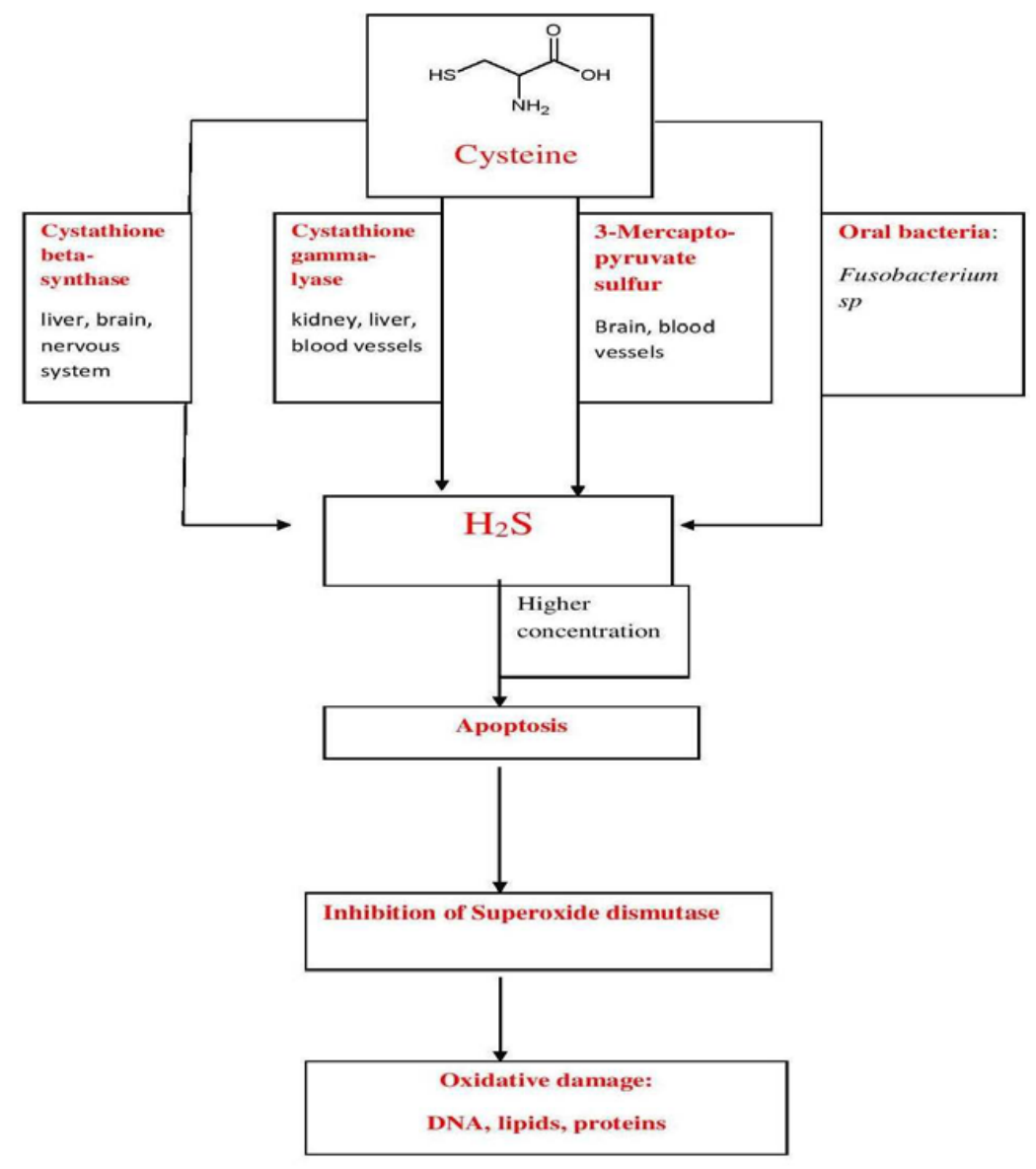

Figure 1. Hydrogen sulfide production-Cysteine biosynthesis pathway is the main pathway responsible for $\mathrm{H}_{2} \mathrm{~S}$ production in mammalian organisms. It usually needs the help of three oral enzymes.

In the oral cavity, human periodontal ligament stem cells (PDLSCs) express $\mathrm{H}_{2} \mathrm{~S}$-synthesizing enzymes CSE and (CBS) [14]. CBS may be the main source of endogenous H2S in PDLSCs [14]. $\mathrm{H}_{2} \mathrm{~S}$ is also caused by the metabolic products of oral sulfate-reducing bacteria [15] that degrade substrates such as cysteine, arginine or tryptophan. Interestingly, gut bacteria produced $\mathrm{H}_{2} \mathrm{~S}$ is considered a pathogenic factor in bowel inflammatory diseases characterised by inflammatory mucosal lesions like periodontal diseases lesions [16].

\section{3. $\mathrm{H}_{2} \mathrm{~S}$ Biological Roles}

$\mathrm{H}_{2} \mathrm{~S}$ is a gaseous mediator with multiple roles depending on the tissue or organ. Thus, $\mathrm{H}_{2} \mathrm{~S}$ is involved in blood vessels dilatation, inflammation, cardiac reaction to ischemic injuries [17], nervous system regulation [18], insulin secretion, and resistance [1,19]. In the human body, increased 
concentrations of $\mathrm{H}_{2} \mathrm{~S}$ are associated with respiratory affections such as chronic bronchitis, emphysema, pneumonia or diseases related to the cardiovascular system (e.g., hypertension) [17]. However, there is also a rapidly expanding body of evidence for essential roles of $\mathrm{H}_{2} \mathrm{~S}$ in the protection against tissue injury, in reducing inflammation, and tissue repair [20]. $\mathrm{H}_{2} \mathrm{~S}$ might be both beneficial and harmful in cerebral ischemic injury depending on its concentration [21]. A recent study found that the amino-oxyacetic acid (AOAA), an inhibitor of $\mathrm{H}_{2} \mathrm{~S}$ synthesis, administered at a low dose has protective effects; but it worsens the ischemic injury at higher concentrations [21].

Among the most studied molecular mechanisms of $\mathrm{H}_{2} \mathrm{~S}$ cellular effects is the regulation of intracellular redox homeostasis and post-translational modification of proteins through glutathione (GSH) generation and S-sulfhydration [1]. Moreover, $\mathrm{H}_{2} \mathrm{~S}$ exerts anti-oxidative, anti-inflammatory and cytoprotective effects [22]. Sodium hydrosulfide ( $\mathrm{NaHS})\left(\mathrm{a} \mathrm{H}_{2} \mathrm{~S}\right.$ donor) had interesting effects in the kidneys of uranium-intoxicated rats: it managed to lower malondialdehyde(MDA) accumulation, and to restore GSH levels and anti-oxidative enzymes' activities like superoxide dismutase (SOD), glutathione peroxidase (GPx), catalase (CAT) and glutathione S-transferase (GST) [22]. Furthermore, a mitochondrially targeted hydrogen sulfide donor exerts protective effects in renal epithelial cells subjected to OS, as it might be related to the reduction of cellular OS [23]. Also, $\mathrm{H}_{2} \mathrm{~S}$ can protect neurons and cardiac muscle from OS and ischemia-reperfusion injury [24], as well as accelerating wound healing in diabetic animals [8].

Likewise, other volatile sulfur compounds related to $\mathrm{H}_{2} \mathrm{~S}$ (i.e., dimethyl sulfide) were shown to be significantly elevated in patients with cerebrovascular pathology (for example, subarachnoid or intracerebral hemorrhages), as well as increased cholesterol levels, asthma or hepatic affections like cirrhosis [25] (Table 1).

Table 1. Hydrogen sulfide—systemic effects.

\begin{tabular}{cc}
\hline Biological Event & $\mathbf{H}_{\mathbf{2}} \mathbf{S}-$ Effect \\
\hline Angiogenesis & Increases blood flow Decreases the risk of tissue injury \\
Mitochondrial respiration & Decreases the function Cytoprotection \\
Vasodilatation & Regulates blood pressure \\
Leukocyte adhesion & Anti-inflammatory effect \\
Apoptosis & Decreases apoptosis-cytoprotective effect \\
Antioxidant & Up-regulation of antioxidant molecules \\
\hline
\end{tabular}

Also, not surprisingly, several studies have focused on the $\mathrm{H}_{2} \mathrm{~S}$ toxicity in the or alenvironment (Tables 2 and 3).

Table 2. Biological effects of high physiological concentrations of $\mathrm{H}_{2} \mathrm{~S}$ on different oral cell types (50 ng/ $\mathrm{mL} \mathrm{H}_{2} \mathrm{~S}$ ).

\begin{tabular}{|c|c|c|c|}
\hline Tissue & Cells & Origin & Biological Event \\
\hline \multirow{4}{*}{ Oral Epithelia } & Normal keratinocytes & Ca9-22 cell line & Apoptosis-mitochondrial pathway activated; DNA damage \\
\hline & Keratinocyte stem cells & Human skin cell line & $\begin{array}{l}\text { Apoptosis-mitochondrial pathway activated; DNA damage; } \\
\text { p53 and Bax activity increased }\end{array}$ \\
\hline & Keratinocyte stem cells & Human oral mucosa & $\begin{array}{l}\text { Apoptosis-mitochondrial pathway activated; DNA damage; } \\
\text { Activation of genes from p53 pathway connected with DNA } \\
\text { repair, cell cycle arrest }\end{array}$ \\
\hline & Keratinocyte cells & Animal oral mucosa & Increases the permeability of the epithelium \\
\hline \multirow{2}{*}{ Oral Dermis } & Fibroblasts & Human oral mucosa & Apoptosis-mitochondrial pathway activated; DNA damage \\
\hline & Collagen Fibers & Extracellular matrix & Increases collagen degradation/decreases collagen synthesis \\
\hline Dental Pulp & Dental pulp stem cells & Human dental pulp & Apoptosis-mitochondrial pathway activated; DNA damage \\
\hline Bone & Osteoblasts & Mouse calvaria & $\begin{array}{l}\text { Apoptosis-mitochondrial and death ligand pathway } \\
\text { activated; DNA damage; Bone resorption }\end{array}$ \\
\hline
\end{tabular}


Table 3. Biological effects of low physiological concentrations of $\mathrm{H}_{2} \mathrm{~S}$ on different oral cell types $\left(1 \mathrm{ng} / \mathrm{mL} \mathrm{H}_{2} \mathrm{~S}\right)$.

\begin{tabular}{cccc}
\hline \multicolumn{2}{c}{ Tissue/Cells } & Origin & Biological Event \\
\hline \multirow{2}{*}{ Dental Pulp } & Dental pulp cells & Human pulp & Differentiation to hepatic like cells \\
\cline { 2 - 4 } & Dental pulp cells & Human pulp & Differentiation of pancreatic like cells \\
\hline Bone & Osteoclasts & Mouse & Osteoclast activation followed by bone resorption \\
\hline
\end{tabular}

\section{Oxidative Stress and Periodontal Diseases}

Reactive oxygen species (ROS) are products of normal oxygen metabolism and have beneficial biological effects, in low levels and under normal conditions. Instead, higher concentrations present harmful effects to the body. External environment (heat, UV light, $\mathrm{X}$ and gamma radiations, therapeutic drugs), behavioural activities (smoking, chronic exercise) and inflammatory cells (such as activated macrophages and neutrophils release various $\mathrm{ROS}\left(\mathrm{H}_{2} \mathrm{O}_{2}, \mathrm{NO}, \mathrm{O}_{2}{ }^{-}, \mathrm{HO}\right.$ and $\left.\mathrm{HOCl}\right)$ [26-29]. Even though ROS have extremely short half-lives, they can cause substantial damage to tissues and cellular components. Recently, systemic OS was also associated with the suppression of bacterial-specific IgG levels [30]. At the cellular level, ROS progression starts with membrane lipid peroxidation followed by cytosolic proteins modification and ending with DNA oxidation [31]. Lipid peroxidation is initiated by the hydroxyl radical, while its major final products are MDA and 4-hydroxyl-2-nonenal (HNE). Therefore, MDA is one of the most used biomarkers to evaluate oxidative damage in both local and systemic disorders [31].

Several amino acids (such as tyrosine) can also react with ROS, generating a wide range of products, from modified and less active enzymes to denatured, non-functioning proteins. Furthermore, mitochondrial DNA are also affected by the ROS attack. HO can react with all components of DNA molecules, damaging both purine and pyrimidine [26-28,32-34].

There are many enzymatic antioxidant defence mechanisms in order to protect against ROS effects in vivo [35]: SOD, GPx, CAT [35-37]. Saliva has its own fighting mechanisms: uric acid, ascorbate, reduced glutathione and alpha tocopherol [38-42]. Urate, the most important salivary antioxidant, acts as a scavenger for hydroxyl radical, singlet oxygen, or peroxynitrite, especially in presence of ascorbic acid or thiols [43]. Other sources of antioxidants in the oral cavity are albumin, catalase-positive commensal and fresh blood extravasated from injured capillaries [42]. More than that, SOD has been localized in the human periodontal ligament, and it is a valuable defence enzyme within gingival fibroblasts $[35,44]$.

Tissue destruction in periodontal diseases is considered to be the result of an altered inflammatory/immune response to microbial plaque and involves massive release of neutrophils, ROS and enzymes [45-48]. Gingival epithelial cells form the first line of defence in the gingival crevice. So, they have the key role as the protection mechanism of host oral structures from bacterial invasion. Thus, gingival epithelial cells produce an adaptive immune responses [49] and release the chemotaxis factor for neutrophils [50,51], antimicrobial peptides [52] and pro-inflammatory cytokines, such as interleukin-8 (IL-8). Unfortunately, on the other hand, over-expression of these pro-inflammatory cytokines causes collateral tissue damage. ROS produced by activated neutrophils in response to periodontopathogenic bacteria cause serious periodontal tissue lesions, in the context of periodontal disease $[28,34,53]$.

Therefore, the balance between antioxidant mechanisms and ROS is of utter importance in periodontal pathogenesis. Increased ROS and inhibited antioxidant mechanisms and/or decreased antioxidant capacity might lead to problems of the periodontium. Several authors reported a positive correlation between periodontal tissue damage and high levels of ROS [54-57]. Hypoxia and inflammation induced higher expression of ROS in primary periodontal ligament fibroblasts [55]. 
Besides, the exposure of periodontal ligament cells to hydrogen peroxide decreased their viability by promoting apoptosis [58].

Furthermore, animals infected with periodontal pathogens presented a five-fold increase in the OS index compared with controls [54]. Clinical studies also confirmed the link between ROS and progression of periodontitis [57]. A meta-analysis of 31 articles concluded that higher amounts of MDA and nitric oxide (NO) could be found in the peripheral blood of periodontal subjects [56]. Interestingly, the authors of the meta-analysis stated that SOD levels between normal and affected adults did not differ very much [56]. However, recent clinical studies encountered significantly lower levels of SOD in the serum [4] and gingival fluid [59] of periodontally diseased subjects. Of main importance are the results presenting higher amounts of total antioxidant capacity (TAC) $[56,60]$ and CAT [61] in the serum of healthy patients. CAT is an enzyme that protects cells from hydrogen peroxide [61] and its decrease might be linked to failure of regulatory antioxidant mechanisms. Of real interest is also the fact that TAC [61] and SOD [4] levels rose significantly after periodontal treatment in the serum of periodontitis patients.

Researchers have also started to consider a possible relationship between periodontitis and systemic diseases. Diabetes mellitus [60,62,63], metabolic syndrome [64] and periodontal disease are all of related by a common factor known as OS. There was a major alteration of the local antioxidant defence mechanism in the gum and/or bone tissues of type 2 diabetes mellitus patients, which presented lower glutathione levels [62]. Interestingly, another clinical study concluded that adults affected by both periodontitis and diabetes mellitus exhibited higher serum values of SOD [60]. The authors considered that this might have been an adaptive mechanism against ROS that were developing in the tissues [60].

Further experiments demonstrated there is an increased amount of ROS not only in serum, but also in the oral fluids of periodontally diseased subjects [59,65]. Gingival crevicular fluid (GCF) of periodontitis sites exhibits a significantly greater total amount of GPx, lactoferrin, myeloperoxidase and interleukin-1beta (IL-1 $\beta$ ) than healthy sites [66]. Moreover, MDA showed to be significantly up regulated in the GCF of adults with chronic and generalized aggressive periodontitis [59]. However, most importantly, saliva of periodontal patients often includes higher expression of oxidative and cellular energetic stress markers, increased purine degradation, GSH metabolism [65] and lower levels of uric acid. The low salivary levels of uric acid in periodontitis patients could be due to elevated rates of oral ROS in the context of chronic inflammatory reactions. Therefore, salivary uric acid might play an essential protective role against ROS and could be regarded as a local ROS marker in the context of chronic periodontitis $[28,34,67]$.

New therapies are constantly being developed and could have future uses against OS present in chronic periodontitis: protein transduction treatments [68], bone targeted antiresorptives(bis-enoxacin and alendronate) [54] or antioxidants [57,58].

Ascorbic acid, an antioxidant, plays an important role in the maintenance of periodontal health in the elderly [69]. Its use led to really promising results in vitro, being able to partially antagonize the negative effects of hydrogen peroxide [58]. Furthermore, the administration of the antioxidant taurine in adults with chronic periodontitis resulted in a significant reduction of ROS present in plasma and gingival tissue, together with an improvement of periodontal status [57]. Other specific strategies could include lactic acid bacteria with antioxidative activity [70] or lipophilic antioxidants [71].

\section{5. $\mathrm{H}_{2} \mathrm{~S}$-Involvement in Periodontal Diseases}

Considering periodontitis a polymicrobial anaerobe infection, researchers focus on the following main mechanisms for explaining its pathogenesis: the production of certain waste products in the proteolytic metabolism, an intense host-inflammatory response and increased OS [2,3,29].

$\mathrm{H}_{2} \mathrm{~S}$ is a bacterial waste product eliminated in the subgingival pocket $[2,3]$ which, due to pro-inflammatory properties, might play an important role in the bacteria-induced inflammatory response in the periodontal diseases [72-75]. Other studies consider that oral malodorous compounds 
including $\mathrm{H}_{2} \mathrm{~S}$ are causative agents of periodontitis because the toxicities are similar to that of cyanate [76]. However, $\mathrm{H}_{2} \mathrm{~S}$ has also shown antioxidant properties, for example, in elevating endogenous antioxidase, such as SOD $[8,77,78]$.

So, $\mathrm{H}_{2} \mathrm{~S}$ can be regarded as a double-faced molecule: on one side, it can promote an antioxidant effect and becomes cytoprotective; while on the other side, it stimulates OS and is cytotoxic.

Reports show that $\mathrm{H}_{2} \mathrm{~S}$ is directly linked to the initiation and development of periodontal diseases: the compound inhibits the proliferation process of oral keratinocyte cells [79], decreases protein synthesis in oral fibroblasts, and inhibits collagen synthesis or basal membrane synthesis [80].

There seems to be a direct relationship between the type of biological effect induced by $\mathrm{H}_{2} \mathrm{~S}$ and the $\mathrm{H}_{2} \mathrm{~S}$ levels. Low physiological concentrations of $\mathrm{H}_{2} \mathrm{~S}$ have been shown to induce dental pulp cells differentiation towards hepatic or pancreatic cells [81] or to switch mouse osteoclasts from a passive state to an active one that induces bone resorption [81]. Moreover, physiological levels of endogenous $\mathrm{H}_{2} \mathrm{~S}$ maintain the proliferation and differentiation of PDLSCs [14]. Blocking the endogenous $\mathrm{H}_{2} \mathrm{~S}$ in PDLSCs led to significant reduction in their proliferation rate, as well as decreased osteogenic and adipogenic differentiation [14]. However, new $\mathrm{H}_{2} \mathrm{~S}$-releasing drugs had enhanced anti-inflammatory effects and reduced side effects in tissues [20]. Recently, a $\mathrm{H}_{2} \mathrm{~S}$-releasing derivative of naproxen, ATB-346, led to significant inhibition of alveolar bone loss and inflammation in periodontal rats [82].

High physiological concentrations of $\mathrm{H}_{2} \mathrm{~S}$ are demonstrated to induce programmed cell death through different molecular pathways in a number of cell types. These concentrations induced apoptosis through inhibition of SOD in human gingival fibroblasts. This enzyme is paramount in eliminating ROS and leads to damage of DNA structure. The same process was observed in normal keratinocytes [83] and keratinocytes stem cells. DNA damage is shown to activate several molecular pathways such as p53 pathway that can decide cellular fate through activation of DNA repair molecules, cell cycle arrest or apoptosis.

Volatile sulfur compounds and especially $\mathrm{H}_{2} \mathrm{~S}$ were shown to induce the apoptotic process in several cell types belonging to oral structures. Generally, apoptosis follows well established pathways such as: intrinsic mitochondrial pathway where the inner mitochondrial membrane is depolarized followed by cytochrome c release into cytosol, assembly of the apoptosome that leads to activation of initiator caspase 9 ultimately followed by executioner caspase 3 activation [84].

This pathway was activated in most studied cell types: oral fibroblasts, oral keratinocytes, oral keratinocyte stem cells, and general keratinocyte stem cells. The extrinsic pathway, or theligand-activated pathway was shown to be responsible for apoptosis induction only in cells isolated from the alveolar bone, osteoblast cells. At the same time, after $\mathrm{H}_{2} \mathrm{~S}$-exposure, human oral keratinocyte stem cells expressed key p53-related molecules associated with cell death, DNA repair and cell cycle control.

Another clinical effect of $\mathrm{H}_{2} \mathrm{~S}$ is its association in the development of physiological and pathological halitosis $[15,49]$. Halitosis is the general term used to describe offensive smells detected in human breath and is a characteristic symptom of periodontal disease [15].

Several studies reported bacterial $\mathrm{H}_{2} \mathrm{~S}$ producing species like Fusobacteriumspp., Parvimonasmicra, Tannerella forsythia or Filifactoralocis [2]. For example, Fusobacteriumspp. acts on substrates such as cysteine [85], homocysteine [86] or GSH [87]. Likewise, a recent study examined the GSH metabolism in Treponemadenticola [88].

Three steps has been proposed for the bacterial $\mathrm{H}_{2} \mathrm{~S}$ production pathway. Glutamate or glutamine and the dipeptide cysteinylglycine (Cys-Gly), are obtained from GSH. Cys-Gly degradation results Gly and L-Cys. Pyruvate, ammonia, and $\mathrm{H}_{2} \mathrm{~S}$ are the final products of L-Cys degradation. In GSH metabolism are involved three enzymes $\gamma$-glutamyltransferase (GGT), cysteinylglycinase, and L-cysteine desulfhydrase (cystalysin) $[89,90]$, the last one cystalysin catalyzes the production of $\mathrm{H}_{2} \mathrm{~S}$, in the presence of L-cysteine $[90,91]$. 
The $\mathrm{H}_{2} \mathrm{~S}$-producing capacity is commonly tested with gas chromatography [89], colorimetric bismuth sulfide precipitation method [92], by using sensors [90] or by blackening of lead acetate paper [91].

In present more research is needed to be done under various conditions both in vitro and in vivo to detect the rate and amount of $\mathrm{H}_{2} \mathrm{~S}$ produced by various species and strains.

In addition to $\mathrm{H}_{2} \mathrm{~S}$, Porphyromonas gingivalis, produces several other virulence factors such as proteases (gingipains) [93], lipopolysaccharide (LPS) [94], and hemagglutinins [95]. A higher level of $\mathrm{H}_{2} \mathrm{~S}(650-1.150 \mu \mathrm{mol} / \mathrm{L})$, produced by Porphyromonas gingivalis affect IL-8 production in Phorbolmyristateacetat (PMA)-stimulated epithelial cells.

A lower concentration of $\mathrm{H}_{2} \mathrm{~S}$ (less than $400 \mu \mathrm{mol} / \mathrm{L}$ ), did not effect IL-8 production in PMA-stimulated epithelial cells [75]. $\mathrm{H}_{2} \mathrm{~S}$ present in blood at concentrations in the range of 30-100 $\mu \mathrm{M}$ [96], epithelial cells can accept $\mathrm{H}_{2} \mathrm{~S}$ in concentrations lower than $400 \mu \mathrm{mol} / \mathrm{L}$. Another study observed that increased levels of $\mathrm{H}_{2} \mathrm{~S}(800$ or $1.600 \mu \mathrm{mol} / \mathrm{L})$ did not stimulate IL-8 production in epithelial cells in the absence of PMA [96].

This means that for $\mathrm{H}_{2} \mathrm{~S}$-mediated production of IL-8, the presence of a predisposed inflammatory condition is very important [75]. This could explain the dual behavior of $\mathrm{H}_{2} \mathrm{~S}$.Additionally, a recent study found that $\mathrm{H}_{2} \mathrm{~S}$ synergistically up regulates Porphyromonas gingivalis LPS-induced expression of IL-6 and IL-8 in gingival fibroblasts and PDLCs, which could further promote the development of periodontitis [97]. Lower concentration of $\mathrm{H}_{2} \mathrm{~S}$ inhibited LPS which induced synthesis of prostaglandin E2 $\left(\mathrm{PGE}_{2}\right), \mathrm{NO}, \mathrm{IL}-1 \beta$ and IL-6 in LPS-treated murine macrophages [98,99]. However, higher concentrations of $\mathrm{NaHS}, \mathrm{a}_{2} \mathrm{~S}$ donor, promoted the synthesis of pro-inflammatory mediators $[98,99]$. An important function of IL-8 is chemo-attraction of neutrophils, which migrate to epithelial cells, the site where IL-8 is released and promote bacteria phagocytosis [100]. Neutrophils promote ROS production in order to kill bacteria cells but these ROS also seriously augment inflammation [101].

IL-8 production by epithelial cells is mediated by $\mathrm{H}_{2} \mathrm{~S}$, causes an enhancement of local inflammation by recruiting excess numbers of neutrophils. Several studies made in vivo on pancreas, liver and lung, observed that both endogenous $\mathrm{H}_{2} \mathrm{~S}$ and exogenously supplied $\mathrm{H}_{2} \mathrm{~S}$ increased neutrophil migration to the inflammation sites [102,103].

These data support the premise that the periodontal bacteria released $\mathrm{H}_{2} \mathrm{~S}$ could induce the chemotaxis of neutrophils to the periodontal pocket, becoming this way, a real promoter of local OS, indirectly.

Exogenous $\mathrm{H}_{2} \mathrm{~S}$ toxic effects in periodontal tissue has been showed [75], but the role of endogenous $\mathrm{H}_{2} \mathrm{~S}$ in periodontal tissue physiologic function remains less understood. A recent study involving 43 subjects with moderate or severe periodontal breakdown could not correlate $\mathrm{H}_{2}$ Sproduction to periodontal disease severity or to a specific bacterial composition [92]. It was suggested that $\mathrm{H}_{2} \mathrm{Smay}$ be a valuable clinical marker for degradation of proteins in the sub gingival pocket [92].

\section{Conclusions}

Altogether, data presented in recent studies suggests that the relationship between $\mathrm{H}_{2} \mathrm{~S}$, OS and periodontal diseases is controversial, but should not be underestimated. Further research is needed in order to elucidate the exact mechanisms and conditions which cause the $\mathrm{H}_{2} \mathrm{~S}$ molecule to exhibit antioxidant or cytotoxic proprieties in the oral cavity.

To date, there is no general consensus regarding $\mathrm{H}_{2} \mathrm{~S}$ biochemistry and its functions in cell biology (i.e., its pro- or anti-inflammatory effects). In this respect, the field can be further expanded together with the development of tools that could correctly identify and quantify $\mathrm{H}_{2} \mathrm{~S}$ synthesis and catabolism in organs and tissues [13]. Another important issue would be the elucidation of endo- or exogenous signals that initiate $\mathrm{H}_{2} \mathrm{~S}$ production together with a better understanding of the chemical pathways responsible for its removal. Overall, a more clear understanding of the biochemistry of $\mathrm{H}_{2} \mathrm{~S}$ in relation to its biological roles is greatly needed. 
Acknowledgments: Daniela Miricescu would like to thank for the Young Scientist Grant 2014-2016 received from University of Medicine and Pharmacy Carol Davila, Bucharest, Romania.

Author Contributions: Maria Greabu: analysis of data, critical revision of manuscript; Alexandra Totan: study design, acquisition of data, critical revision of the manuscript; Justina Virlan: study design, acquisition of data, manuscript revision; Daniela Miricescu: analysis of data; Bogdan Calenic: analysis of data; Radu Radulescu: analysis of data.

Conflicts of Interest: The authors declare no conflict of interest.

\section{References}

1. Ju, Y.; Zhang, W.; Pei, Y.; Yang, G. $\mathrm{H}_{2} \mathrm{~S}$ signaling in redox regulation of cellular functions. Can. J. Physiol. Pharmacol. 2013, 91, 8-14. [CrossRef] [PubMed]

2. Persson, S.; Edlund, M.B.; Claesson, R.; Carlsson, J. The formation of hydrogen sulfide and methyl mercaptan by oral bacteria. Oral Microbiol. Immunol. 1990, 5, 195-201. [CrossRef]

3. Persson, S. Hydrogen sulfide and methyl mercaptan in periodontal pockets. Oral Microbiol. Immunol. 1992, 7, 378-379. [CrossRef] [PubMed]

4. Biju, T.; Shabeer, M.M.; Amitha, R.; Rajendra, B.P.; Suchetha, K. Comparative evaluation of serum superoxide dismutase and glutathione levels in periodontally diseased patients: An interventional study. Indian J. Dent. Res. 2014, 25, 613-616. [PubMed]

5. Mancini, S.; Romanelli, R.; Laschinger, C.A.; Overall, C.M.; Sodek, J.; McCulloch, C.A. Assessment of a novel screening test for neutrophil collagenase activity in the diagnosis of periodontal diseases. J. Periodontol. 1999, 70, 1292-1302. [CrossRef] [PubMed]

6. Vacek, T.P.; Gillespie, W.; Tyagi, N.; Vacek, J.C.; Tyagi, S.C. Hydrogen sulfide protects against vascular remodeling from endothelial damage. Amino Acids 2010, 39, 1161-1169. [CrossRef] [PubMed]

7. Calvert, J.W.; Jha, S.; Gundewar, S.; Elrod, J.W.; Ramachandran, A.; Pattillo, C.B.; Kevil, C.G.; Lefer, D.J. Hydrogen sulfide mediates cardioprotection through Nrf2 signaling. Circ. Res. 2009, 105, 365-374. [CrossRef] [PubMed]

8. Wang, G.; Li, W.; Chen, Q.; Jiang, Y.; Lu, X.; Zhao, X. Hydrogen sulfide accelerates wound healing in diabetic rats. Int. J. Clin. Exp. Pathol. 2015, 8, 5097-5104. [PubMed]

9. Zanardo, R.C.; Brancaleone, V.; Distrutti, E.; Fiorucci, S.; Cirino, G.; Wallace, J.L. Hydrogen sulfide is an endogenous modulator of leukocyte-mediated inflammation. FASEB J. 2006, 20, 2118-2120. [CrossRef] [PubMed]

10. Predmore, B.L.; Lefer, D.J.; Gojon, G. Hydrogen sulfide in biochemistry and medicine. Antioxid. Redox Signal. 2012, 17, 119-140. [CrossRef] [PubMed]

11. Kimura, H. Hydrogen sulfide and polysulfides as signaling molecules. Proc. Jpn. Acad. Ser. B Phys. Biol. Sci. 2015, 91, 131-159. [CrossRef] [PubMed]

12. Kasparek, M.S.; Linden, D.R.; Kreis, M.E.; Sarr, M.G. Gasotransmitters in the gastrointestinal tract. Surgery 2008, 143, 455-459. [CrossRef] [PubMed]

13. Nagy, P.; Palinkas, Z.; Nagy, A.; Budai, B.; Toth, I.; Vasas, A. Chemical aspects of hydrogen sulfide measurements in physiological samples. Biochim. Biophys. Acta 2014, 1840, 876-891. [CrossRef] [PubMed]

14. Su, Y.; Liu, D.; Liu, Y.; Zhang, C.; Wang, J.; Wang, S. Physiologic levels of endogenous hydrogen sulfide maintain the proliferation and differentiation capacity of periodontal ligament stem cells. J. Periodontol. 2015, 86, 1276-1286. [CrossRef] [PubMed]

15. Ratcliff, P.A.; Johnson, P.W. The relationship between oral malodor, gingivitis, and periodontitis. A review. J. Periodontol. 1999, 70, 485-489. [CrossRef] [PubMed]

16. Sigusch, B.W. Periodontitis as manifestation of Crohn's disease in primary dentition: A case report. J. Dent. Child. 2004, 71, 193-196.

17. Calvert, J.W.; Coetzee, W.A.; Lefer, D.J. Novel insights into hydrogen sulfide-Mediated cytoprotection. Antioxid. Redox Signal. 2010, 12, 1203-1217. [CrossRef] [PubMed]

18. Pae, H.O.; Lee, Y.C.; Jo, E.K.; Chung, H.T. Subtle interplay of endogenous bioactive gases (NO, $\mathrm{CO}$ and $\left.\mathrm{H}_{2} \mathrm{~S}\right)$ in inflammation. Arch. Pharm. Res. 2009, 32, 1155-1162. [CrossRef] [PubMed]

19. Wang, R. Physiological implications of hydrogen sulfide: A whiff exploration that blossomed. Physiol. Rev. 2012, 92, 791-896. [CrossRef] [PubMed] 
20. Wallace, J.L.; Blackler, R.W.; Chan, M.V.; Da Silva, G.J.; Elsheikh, W.; Flannigan, K.L.; Gamaniek, I.; Manko, A.; Wang, L.; Motta, J.P.; et al. Anti-inflammatory and cytoprotective actions of hydrogen sulfide: Translation to therapeutics. Antioxid. Redox Signal. 2015, 22, 398-410. [CrossRef] [PubMed]

21. Hadadha, M.; Vakili, A.; Bandegi, A.R. Effect of the inhibition of hydrogen sulfide synthesis on ischemic injury and oxidative stress biomarkers in a transient model of focal cerebral ischemia in rats. J. Stroke Cerebrovasc. Dis. 2015, 24, 2676-2684. [CrossRef] [PubMed]

22. Zheng, J.; Zhao, T.; Yuan, Y.; Hu, N.; Tang, X. Hydrogen sulfide $\left(\mathrm{H}_{2} \mathrm{~S}\right)$ attenuates uranium-induced acute nephrotoxicity through oxidative stress and inflammatory response via Nrf2-NF-kB pathways. Chem. Biol. Interact. 2015, 242, 353-362. [CrossRef] [PubMed]

23. Ahmad, A.; Olah, G.; Szczesny, B.; Wood, M.E.; Whiteman, M.; Szabo, C. Ap39, a mitochondrially-targeted hydrogen sulfide donor, exerts protective effects in renal epithelial cells subjected to oxidative stress in vitro and in acute renal injury in vivo. Shock 2016, 45, 88-97. [CrossRef] [PubMed]

24. Kimura, H.; Shibuya, N.; Kimura, Y. Hydrogen sulfide is a signaling molecule and a cytoprotectant. Antioxid. Redox Signal. 2012, 17, 45-57. [CrossRef] [PubMed]

25. Li, L.; Rose, P.; Moore, P.K. Hydrogen sulfide and cell signaling. Annu. Rev. Pharmacol. Toxicol. 2011, 51, 169-187. [CrossRef] [PubMed]

26. Valko, M.; Leibfritz, D.; Moncol, J.; Cronin, M.T.; Mazur, M.; Telser, J. Free radicals and antioxidants in normal physiological functions and human disease. Int. J. Biochem. Cell Biol. 2007, 39, 44-84. [CrossRef] [PubMed]

27. Huertas, J.R.; Palomino, N.; Ochoa, J.J.; Quiles, J.L.; Ramirez-Tortosa, M.C.; Battino, M.; Robles, R.; Mataix, J. Lipid peroxidation and antioxidants in erythrocyte membranes of full-term and preterm newborns. BioFactors 1998, 8, 133-137. [CrossRef] [PubMed]

28. Miricescu, D.; Totan, A.; Calenic, B.; Mocanu, B.; Didilescu, A.; Mohora, M.; Spinu, T.; Greabu, M. Salivary biomarkers: Relationship between oxidative stress and alveolar bone loss in chronic periodontitis. Acta Odontol. Scand. 2014, 72, 42-47. [CrossRef] [PubMed]

29. Greabu, M.; Calenic, B. Salivary biomarkers of oxidative stress associated with periodontal diseases. In Studies on Periodontal Disease; Ekuni, D., Battino, M., Tomofuji, T., Putnins, E.E., Eds.; Springer: New York, NY, USA, 2014; pp. 329-343.

30. Singer, R.E.; Moss, K.; Kim, S.J.; Beck, J.D.; Offenbacher, S. Oxidative stress and IgG antibody modify periodontitis-CRP association. J. Dent. Res. 2015, 94, 1698-1705. [CrossRef] [PubMed]

31. Su, H.; Gornitsky, M.; Velly, A.M.; Yu, H.; Benarroch, M.; Schipper, H.M. Salivary DNA, lipid, and protein oxidation in nonsmokers with periodontal disease. Free Radic. Biol. Med. 2009, 46, 914-921. [CrossRef] [PubMed]

32. Mohora, M.; Greabu, M.; Totan, A.; Mitrea, N.; Battino, M. Redox-sensitive signaling factors and antioxidants. Farmacia 2009, 57, 399-411.

33. Totan, A.; Miricescu, D.; Parlatescu, I.; Mohora, M.; Greabu, M. Possible salivary and serum biomarkers for oral lichen planus. Biotechnic. Histochem. 2015, 90, 552-558. [CrossRef] [PubMed]

34. Miricescu, D.; Greabu, M.; Totan, A.; Mohora, M.; Didilescu, A.; Mitrea, N.; Arsene, A.; Spinu, T.; Totan, C.; Rădulescu, R. Oxidative stress-A possible link between systemic and oral diseases. Farmacia 2011, 59, 329-337.

35. Jenifer, H.D.; Bhola, S.; Kalburgi, V.; Warad, S.; Kokatnur, V.M. The influence of cigarette smoking on blood and salivary super oxide dismutase enzyme levels among smokers and nonsmokers-A cross sectional study. J. Tradit. Complement. Med. 2015, 5, 100-105. [CrossRef] [PubMed]

36. Chapple, I.L.; Mason, G.I.; Garner, I.; Matthews, J.B.; Thorpe, G.H.; Maxwell, S.R.; Whitehead, T.P. Enhanced chemiluminescent assay for measuring the total antioxidant capacity of serum, saliva and crevicular fluid. Ann. Clin. Biochem. 1997, 34, 412-421. [CrossRef] [PubMed]

37. Tonguc, M.O.; Ozturk, O.; Sutcu, R.; Ceyhan, B.M.; Kilinc, G.; Sonmez, Y.; Yetkin Ay, Z.; Sahin, U.; Baltacioglu, E.; Kirzioglu, F.Y. The impact of smoking status on antioxidant enzyme activity and malondialdehyde levels in chronic periodontitis. J. Periodontol. 2011, 82, 1320-1328. [CrossRef] [PubMed]

38. Sculley, D.V.; Langley-Evans, S.C. Salivary antioxidants and periodontal disease status. Proc. Nutr. Soc. 2002, 61, 137-143. [CrossRef] [PubMed]

39. Nagler, R.M.; Klein, I.; Zarzhevsky, N.; Drigues, N.; Reznick, A.Z. Characterization of the differentiated antioxidant profile of human saliva. Free Radic. Biol. Med. 2002, 32, 268-277. [CrossRef] 
40. Amerongen, A.V.; Veerman, E.C. Saliva-The defender of the oral cavity. Oral Dis. 2002, 8, 12-22. [CrossRef] [PubMed]

41. Liskmann, S.; Vihalemm, T.; Salum, O.; Zilmer, K.; Fischer, K.; Zilmer, M. Characterization of the antioxidant profile of human saliva in peri-implant health and disease. Clin. Oral Implant. Res. 2007, 18, 27-33. [CrossRef] [PubMed]

42. Ginsburg, I.; Kohen, R.; Shalish, M.; Varon, D.; Shai, E.; Koren, E. The oxidant-scavenging abilities in the oral cavity may be regulated by a collaboration among antioxidants in saliva, microorganisms, blood cells and polyphenols: A chemiluminescence-based study. PLoS ONE 2013, 8. [CrossRef]

43. Wu, Y.; Shu, R.; Luo, L.J.; Ge, L.H.; Xie, Y.F. Initial comparison of proteomic profiles of whole unstimulated saliva obtained from generalized aggressive periodontitis patients and healthy control subjects. J. Periodontal Res. 2009, 44, 636-644. [CrossRef] [PubMed]

44. Agnihotri, R.; Pandurang, P.; Kamath, S.U.; Goyal, R.; Ballal, S.; Shanbhogue, A.Y.; Kamath, U.; Bhat, G.S.; Bhat, K.M. Association of cigarette smoking with superoxide dismutase enzyme levels in subjects with chronic periodontitis. J. Periodontol. 2009, 80, 657-662. [CrossRef] [PubMed]

45. Canakci, C.F.; Cicek, Y.; Canakci, V. Reactive oxygen species and human inflammatory periodontal diseases. Biochemistry 2005, 70, 619-628. [CrossRef] [PubMed]

46. Wong, D.T. Salivary diagnostics powered by nanotechnologies, proteomics and genomics. JADA 2006, 137, 313-321. [CrossRef] [PubMed]

47. Lee, J.; Garon, E.; Wong, D. Salivary diagnostics. Orthod. Craniofac. Res. 2009, 12, 206-211. [CrossRef] [PubMed]

48. Pihlstrom, B.L.; Michalowicz, B.S.; Johnson, N.W. Periodontal diseases. Lancet 2005, 366, $1809-1820$. [CrossRef]

49. Matsuyama, T.; Kawai, T.; Izumi, Y.; Taubman, M.A. Expression of major histocompatibility complex class II and CD80 by gingival epithelial cells induces activation of $\mathrm{CD} 4^{+} \mathrm{T}$ cells in response to bacterial challenge. Infect. Immun. 2005, 73, 1044-1051. [CrossRef] [PubMed]

50. Huang, G.T.; Haake, S.K.; Kim, J.W.; Park, N.H. Differential expression of interleukin-8 and intercellular adhesion molecule- 1 by human gingival epithelial cells in response to Actinobacillus actinomycetemcomitans or Porphyromonas gingivalis infection. Oral Microbiol. Immunol. 1998, 13, 301-309. [CrossRef] [PubMed]

51. Asai, Y.; Ohyama, Y.; Gen, K.; Ogawa, T. Bacterial fimbriae and their peptides activate human gingival epithelial cells through toll-like receptor 2. Infect. Immun. 2001, 69, 7387-7395. [CrossRef] [PubMed]

52. Hosokawa, I.; Hosokawa, Y.; Komatsuzawa, H.; Goncalves, R.B.; Karimbux, N.; Napimoga, M.H.; Seki, M.; Ouhara, K.; Sugai, M.; Taubman, M.A.; et al. Innate immune peptide LL-37 displays distinct expression pattern from beta-defensins in inflamed gingival tissue. Clin. Exp. Immunol. 2006, 146, 218-225. [CrossRef] [PubMed]

53. Almerich-Silla, J.M.; Montiel-Company, J.M.; Pastor, S.; Serrano, F.; Puig-Silla, M.; Dasi, F. Oxidative stress parameters in saliva and its association with periodontal disease and types of bacteria. Dis. Markers 2015, 2015. [CrossRef] [PubMed]

54. Oktay, S.; Chukkapalli, S.S.; Rivera-Kweh, M.F.; Velsko, I.M.; Holliday, L.S.; Kesavalu, L. Periodontitis in rats induces systemic oxidative stress that is controlled by bone-targeted antiresorptives. J. Periodontol. 2015, 86, 137-145. [CrossRef] [PubMed]

55. Golz, L.; Memmert, S.; Rath-Deschner, B.; Jager, A.; Appel, T.; Baumgarten, G.; Gotz, W.; Frede, S. LPS from P. gingivalis and hypoxia increases oxidative stress in periodontal ligament fibroblasts and contributes to periodontitis. Mediat. Inflamm. 2014, 2014. [CrossRef] [PubMed]

56. Liu, Z.; Liu, Y.; Song, Y.; Zhang, X.; Wang, S.; Wang, Z. Systemic oxidative stress biomarkers in chronic periodontitis: A meta-analysis. Dis. Markers 2014, 2014. [CrossRef] [PubMed]

57. Sree, S.L.; Sethupathy, S. Evaluation of the efficacy of taurine as an antioxidant in the management of patients with chronic periodontitis. Dent. Res. J. 2014, 11, 228-233.

58. Wu, W.; Yang, N.; Feng, X.; Sun, T.; Shen, P.; Sun, W. Effect of vitamin C administration on hydrogen peroxide-induced cytotoxicity in periodontal ligament cells. Mol. Med. Rep. 2015, 11, 242-248. [CrossRef] [PubMed]

59. Ghallab, N.A.; Hamdy, E.; Shaker, O.G. Malondialdehyde, superoxide dismutase and melatonin levels in GCF of aggressive and chronic periodontitis patients. Aust. Dent. J. 2015. [CrossRef] [PubMed] 
60. Thomas, B.; Rao, A.; Prasad, B.R.; Kumari, S. Serum levels of antioxidants and superoxide dismutase in periodontitis patients with diabetes type 2. J. Indian Soc. Periodontol. 2014, 18, 451-455. [PubMed]

61. Thomas, B.; Madani, S.M.; Prasad, B.R.; Kumari, S. Comparative evaluation of serum antioxidant levels in periodontally diseased patients: An interventional study. Contemp. Clin. Dent. 2014, 5, 340-344. [PubMed]

62. Monea, A.; Mezei, T.; Popsor, S.; Monea, M. Oxidative stress: A link between diabetes mellitus and periodontal disease. Int. J. Endocrinol. 2014, 2014. [CrossRef] [PubMed]

63. Pushparani, D.S.; Anandan, S.N.; Theagarayan, P. Serum zinc and magnesium concentrations in type 2 diabetes mellitus with periodontitis. J. Indian Soc. Periodontol. 2014, 18, 187-193. [CrossRef] [PubMed]

64. Gurav, A.N. The association of periodontitis and metabolic syndrome. Dent. Res. J. 2014, 11, 1-10.

65. Barnes, V.M.; Kennedy, A.D.; Panagakos, F.; Devizio, W.; Trivedi, H.M.; Jonsson, T.; Guo, L.; Cervi, S.; Scannapieco, F.A. Global metabolomic analysis of human saliva and plasma from healthy and diabetic subjects, with and without periodontal disease. PLOS ONE 2014, 9. [CrossRef] [PubMed]

66. Wei, P.F.; Ho, K.Y.; Ho, Y.P.; Wu, Y.M.; Yang, Y.H.; Tsai, C.C. The investigation of glutathione peroxidase, lactoferrin, myeloperoxidase and interleukin-1beta in gingival crevicular fluid: Implications for oxidative stress in human periodontal diseases. J. Periodontal Res. 2004, 39, 287-293. [CrossRef] [PubMed]

67. Miricescu, D.; Greabu, M.; Totan, A.; Didilescu, A.; Rădulescu, R. The antioxidant potential of saliva: Clinical significance in oral diseases. Ther. Pharmacol. Clin. Toxicol. 2011, 15, 139-143.

68. Kanzaki, H.; Shinohara, F.; Kajiya, M.; Kodama, T. The Keap1/Nrf2 protein axis plays a role in osteoclast differentiation by regulating intracellular reactive oxygen species signaling. J. Biol. Chem. 2013, 288, 23009-23020. [CrossRef] [PubMed]

69. Alagl, A.S.; Bhat, S.G. Ascorbic acid: New role of an age-old micronutrient in the management of periodontal disease in older adults. Geriatr. Gerontol. Int. 2015, 15, 241-254. [CrossRef] [PubMed]

70. Mendi, A.; Aslim, B. Antioxidant lactobacilli could protect gingival fibroblasts against hydrogen peroxide: A preliminary in vitro study. Probiotics Antimicrob. Proteins 2014, 6, 157-164. [CrossRef] [PubMed]

71. Bullon, P.; Roman-Malo, L.; Marin-Aguilar, F.; Alvarez-Suarez, J.M.; Giampieri, F.; Battino, M.; Cordero, M.D. Lipophilic antioxidants prevent lipopolysaccharide-induced mitochondrial dysfunction through mitochondrial biogenesis improvement. Pharmacol. Res. 2015, 91, 1-8. [CrossRef] [PubMed]

72. Rizzo, A.A. The possible role of hydrogen sulfide in human periodontal disease. I. Hydrogen sulfide production in periodontal pockets. Periodontics 1967, 5, 233-236. [PubMed]

73. Morhart, R.E.; Mata, L.J.; Sinskey, A.J.; Harris, R.S. A microbiological and biochemical study of gingival crevice debris obtained from Guatemalan Mayan Indians. J. Periodontol. 1970, 41, 644-649. [CrossRef] [PubMed]

74. Horowitz, A.; Folke, L.E. Hydrogen sulfide production in the periodontal environment. J. Periodontol. 1973, 44, 390-395. [CrossRef] [PubMed]

75. Chen, W.; Kajiya, M.; Giro, G.; Ouhara, K.; Mackler, H.E.; Mawardi, H.; Boisvert, H.; Duncan, M.J.; Sato, K.; Kawai, T. Bacteria-derived hydrogen sulfide promotes IL-8 production from epithelial cells. Biochem. Biophys. Res. Commun. 2010, 391, 645-650. [CrossRef] [PubMed]

76. Imai, T.; Ii, H.; Yaegaki, K.; Murata, T.; Sato, T.; Kamoda, T. Oral malodorous compound inhibits osteoblast proliferation. J. Periodontol. 2009, 80, 2028-2034. [CrossRef] [PubMed]

77. Sivarajah, A.; Collino, M.; Yasin, M.; Benetti, E.; Gallicchio, M.; Mazzon, E.; Cuzzocrea, S.; Fantozzi, R.; Thiemermann, C. Anti-apoptotic and anti-inflammatory effects of hydrogen sulfide in a rat model of regional myocardial I/R. Shock 2009, 31, 267-274. [CrossRef] [PubMed]

78. Searcy, D.G.; Whitehead, J.P.; Maroney, M.J. Interaction of Cu, Zn superoxide dismutase with hydrogen sulfide. Arch. Biochem. Biophys. 1995, 318, 251-263. [CrossRef] [PubMed]

79. Calenic, B.; Yaegaki, K.; Kozhuharova, A.; Imai, T. Oral malodorous compound causes oxidative stress and p53-mediated programmed cell death in keratinocyte stem cells. J. Periodontol. 2010, 81, 1317-1323. [CrossRef] [PubMed]

80. Calenic, B.; Amann, A. Detection of volatile malodorous compounds in breath: Current analytical techniques and implications in human disease. Bioanalysis 2014, 6, 357-376. [CrossRef] [PubMed]

81. Aoyama, I.; Calenic, B.; Imai, T.; Ii, H.; Yaegaki, K. Oral malodorous compound causes caspase-8 and -9 mediated programmed cell death in osteoblasts. J. Periodontal Res. 2012, 47, 365-373. [CrossRef] [PubMed] 
82. Herrera, B.S.; Coimbra, L.S.; da Silva, A.R.; Teixeira, S.A.; Costa, S.K.; Wallace, J.L.; Spolidorio, L.C.; Muscara, M.N. The $\mathrm{H}_{2} \mathrm{~S}$-releasing naproxen derivative, ATB-346, inhibits alveolar bone loss and inflammation in rats with ligature-induced periodontitis. Med. Gas. Res. 2015, 5. [CrossRef] [PubMed]

83. Murata, T.; Yaegaki, K.; Qian, W.; Herai, M.; Calenic, B.; Imai, T.; Sato, T.; Tanaka, T.; Kamoda, T.; Ii, H. Hydrogen sulfide induces apoptosis in epithelial cells derived from human gingiva. J. Breath Res. 2008, 2. [CrossRef] [PubMed]

84. Inoue, S.; Browne, G.; Melino, G.; Cohen, G.M. Ordering of caspases in cells undergoing apoptosis by the intrinsic pathway. Cell Death Differ. 2009, 16, 1053-1061. [CrossRef] [PubMed]

85. Pianotti, R.; Lachette, S.; Dills, S. Desulfuration of cysteine and methionine by fusobacterium nucleatum. J. Dent. Res. 1986, 65, 913-917. [CrossRef] [PubMed]

86. Yoshida, A.; Yoshimura, M.; Ohara, N.; Yoshimura, S.; Nagashima, S.; Takehara, T.; Nakayama, K. Hydrogen sulfide production from cysteine and homocysteine by periodontal and oral bacteria. J. Periodontol. 2009, 80, 1845-1851. [CrossRef] [PubMed]

87. Carlsson, J.; Larsen, J.T.; Edlund, M.B. Peptostreptococcus micros has a uniquely high capacity to form hydrogen sulfide from glutathione. Oral Microbiol. Immunol. 1993, 8, 42-45. [CrossRef] [PubMed]

88. Chu, L.; Dong, Z.; Xu, X.; Cochran, D.L.; Ebersole, J.L. Role of glutathione metabolism of Treponema denticola in bacterial growth and virulence expression. Infect. Immun. 2002, 70, 1113-1120. [CrossRef] [PubMed]

89. Chu, L.; Ebersole, J.L.; Kurzban, G.P.; Holt, S.C. Cystalysin, a 46-kilodalton cysteine desulfhydrase from Treponema denticola, with hemolytic and hemoxidative activities. Infect. Immun. 1997, 65, 3231-3238. [PubMed]

90. Chu, L.; Ebersole, J.L.; Kurzban, G.P.; Holt, S.C. Cystalysin, a 46-kda L-cysteine desulfhydrase from Treponema denticola: Biochemical and biophysical characterization. Clin. Infect. Dis. 1999, 28, 442-450. [CrossRef] [PubMed]

91. Chu, L.; Ebersole, J.L.; Holt, S.C. Hemoxidation and binding of the 46-kda cystalysin of Treponema denticola leads to a cysteine-dependent hemolysis of human erythrocytes. Oral Microbiol. Immunol. 1999, 14, $293-303$. [CrossRef] [PubMed]

92. Basic, A.; Dahlen, G. Hydrogen sulfide production from subgingival plaque samples. Anaerobe 2015, 35, 21-27. [CrossRef] [PubMed]

93. Hagewald, S.; Bernimoulin, J.P.; Kottgen, E.; Kage, A. Total IgA and Porphyromonas gingivalis-reactive IgA in the saliva of patients with generalised early-onset periodontitis. Eur. J. Oral Sci. 2000, 108, 147-153. [CrossRef] [PubMed]

94. Bainbridge, B.W.; Darveau, R.P. Porphyromonas gingivalis lipopolysaccharide: An unusual pattern recognition receptor ligand for the innate host defense system. Acta Odontol. Scand. 2001, 59, 131-138. [CrossRef] [PubMed]

95. McBride, B.C.; Joe, A.; Singh, U. Cloning of bacteroides gingivalis surface antigens involved in adherence. Arch. Oral Biol. 1990, 35 (Suppl. S59-S68). [CrossRef]

96. Wang, R. Two's company, three's a crowd: $\mathrm{Can} \mathrm{H}_{2} \mathrm{~S}$ be the third endogenous gaseous transmitter? FASEB J. 2002, 16, 1792-1798. [CrossRef] [PubMed]

97. Chi, X.P.; Ouyang, X.Y.; Wang, Y.X. Hydrogen sulfide synergistically upregulates Porphyromonas gingivalis lipopolysaccharide-induced expression of IL-6 and IL-8 via NF-kB signalling in periodontal fibroblasts. Arch. Oral Biol. 2014, 59, 954-961. [CrossRef] [PubMed]

98. Whiteman, M.; Li, L.; Rose, P.; Tan, C.H.; Parkinson, D.B.; Moore, P.K. The effect of hydrogen sulfide donors on lipopolysaccharide-induced formation of inflammatory mediators in macrophages. Antioxid. Redox Signal. 2010, 12, 1147-1154. [CrossRef] [PubMed]

99. Fox, B.; Schantz, J.T.; Haigh, R.; Wood, M.E.; Moore, P.K.; Viner, N.; Spencer, J.P.; Winyard, P.G.; Whiteman, M. Inducible hydrogen sulfide synthesis in chondrocytes and mesenchymal progenitor cells: $\mathrm{Is}_{2} \mathrm{~S}$ a novel cytoprotective mediator in the inflamed joint? J. Cell Mol. Med. 2012, 16, 896-910. [CrossRef] [PubMed]

100. Matsushima, K.; Oppenheim, J.J. Interleukin 8 and MCAF: Novel inflammatory cytokines inducible by IL1 and TNF. Cytokine 1989, 1, 2-13. [CrossRef]

101. Jacquot, J.; Tabary, O.; Le Rouzic, P.; Clement, A. Airway epithelial cell inflammatory signalling in cystic fibrosis. Int. J. Biochem. Cell Biol. 2008, 40, 1703-1715. [CrossRef] [PubMed] 
102. Bhatia, M.; Wong, F.L.; Fu, D.; Lau, H.Y.; Moochhala, S.M.; Moore, P.K. Role of hydrogen sulfide in acute pancreatitis and associated lung injury. FASEB J. 2005, 19, 623-625. [CrossRef] [PubMed]

103. Li, L.; Bhatia, M.; Zhu, Y.Z.; Zhu, Y.C.; Ramnath, R.D.; Wang, Z.J.; Anuar, F.B.; Whiteman, M.; Salto-Tellez, M.; Moore, P.K. Hydrogen sulfide is a novel mediator of lipopolysaccharide-induced inflammation in the mouse. FASEB J. 2005, 19, 1196-1198. [CrossRef] [PubMed]

(c) 2016 by the authors; licensee MDPI, Basel, Switzerland. This article is an open access article distributed under the terms and conditions of the Creative Commons by Attribution (CC-BY) license (http://creativecommons.org/licenses/by/4.0/). 